\title{
ISOLASI DAN IDENTIFIKASI FUNGI MIKORIZA ARBUSKULA (FMA) PADA BERBAGAI VARIETAS DAN UMUR KOPI ARABIKA (Coffea arabica L.) DI KECAMATAN TIMANG GAJAH KABUPATEN BENER MERIAH \\ (Isolation and Identification of Arbuscular Mycorrhizal Fungi (AMF) in Various Varieties and Ages of Arabica Coffee (Coffea arabica L.) in Timang Gajah District, Bener Meriah Regency)
}

\author{
Riko Syahputra ${ }^{1}$, Fikrinda Fikrinda ${ }^{1}$, Hifnalisa Hifnalisa ${ }^{1 *}$ \\ ${ }^{1}$ Program Studi Ilmu Tanah, Fakultas Pertanian, Universitas Syiah Kuala \\ *Corresponding author: hifnalisa@unsyiah.ac.id
}

\begin{abstract}
Abstrak. Fungi mikoriza arbuskula (FMA) merupakan tipe asosiasi mikoriza yang tersebar sangat luas, fungi ini yang memiliki peran dan manfaat yang penting dalam dunia pertanian. Penelitian bertujuan mengetahui keanekaragaman FMA, jumlah spesies spora FMA, dan kolonisasi FMA pada rizosfer berbagai varietas dan umur tanaman kopi arabika di Kecamatan Timang Gajah, Kabupaten Bener Meriah. Penilitian dilaksanakan di perkebunan kopi rakyat di Desa Lampahan Barat dan Desa Mude Benara, Kecamatan Timang Gajah, Kabupaten Bener Meriah. Masing-masing varietas dan umur diambil sebanyak 3 titik, sehingga didapatkan sebanyak 24 sampel. Sampel tanah tersebut digunakan untuk mengisolasi jenis FMA yang terdapat di lahan tersebut. Analisis beberapa sifat kimia dan fisika juga dilakukan untuk mendapatkan data pendukung seperti, $\mathrm{pH} \mathrm{H} 2 \mathrm{O}, \mathrm{C}$-Organik, N-Total, P-Tersedia, KTK, dan Tekstur. Analisis beberapa sifat kimia dan fisika tanah dilakukan terhadap sampel tanah komposit dari setiap titik sampel, untuk setiap varietas dan umur kopi arabika. Parameter pengamatan yang dilakukan meliputi: Kepadatan spora FMA, identifikasi jenis spora FMA, dan kolonisasi FMA. Hasil pengamatan menunjukkan terdapat tiga genus FMA yang didapat pada rizosfer beberapa varietas dan umur kopi arabika di Kecamatan Timang Gajah yaitu Glomus, Acaulospora dan, Gigaspora.Terdapat Genus Glomus sebanyak dua spesies, sedangkan genus Acaulospora dan genus Gigaspora sebanyak empat spesies. Kepadatan spora FMA terbanyak ditemukan pada tanaman kopi arabika varietas Tim-Tim berumur lima tahun. Kolonisasi FMA pada akar kopi arabika pada beberapa varietas tergolong kriteria sangat rendah hingga rendah.
\end{abstract}

Kata Kunci: Mikoriza, Kopi Arabika, Timang Gajah.

\begin{abstract}
Arbuscular mycorrhizal fungi (AMF) are a very widespread type of mycorrhizal association, these fungi which have important roles and benefits in agriculture. The research aimed to determine the diversity of AMF, the number of AMF spore species, and AMF colonization in the rhizosphere of various varieties and ages of Arabica coffee plants in Timang Gajah District, Bener Meriah Regency. The research was carried out in coffee plantations in West Lampahan and Mude Benara Village, Timang Gajah District, Bener Meriah Regency. 3 points were taken for each variety and age, so that 24 samples were obtained. The AMF was isolated by using soil samples which found in the land. The chemical and physical analysis properties was also carried out to obtain supporting data such as $\mathrm{pH}, \mathrm{H} 2 \mathrm{O}, \mathrm{C}-\mathrm{Organic}, \mathrm{N}$-Total, P-Available, CEC, and Texture. Analysis of several chemical and physical properties of soil was carried out on composite soil samples from each sample point, for each variety and age of Arabica coffee. Observation parameters carried out included: AMF spore density, identification of AMF spore types, and AMF colonization. The results showed that there were three AMF genera obtained in the rhizosphere of several varieties and ages of Arabica coffee in the District of Timang Gajah, namely Glomus, Acaulospora, and, Gigaspora. There are two species of genus Glomus, while four species of genus Acaulospora and Gigaspora. The highest density of AMF spores was found in the five-year-old Tim-Tim arabica coffee plant. AMF colonization in arabica coffee roots in several varieties was classified as very low to low criteria.
\end{abstract}

Keywords: Mycorrhiza, Arabica Coffee, Timang Gajah.

\section{PENDAHULUAN}

Kabupaten Bener Meriah merupakan satu dari daerah penanaman kopi arabika terluas di Indonesia. Kecamatan Timang Gajah adalah salah satu daerah yang membudidayakan tanaman kopi arabika di Kabupaten Bener Meriah. Jenis varietas kopi arabika yang 
dibudidayakan di wilayah tersebut terdiri atas varietas Gayo 1, Gayo 2, Ateng Super, TimTim dan lainnya. Penanaman kopi arabika di daerah ini umumnya dilakukan pada Andisol (Khalid, 2017).

Retensi P yang tinggi adalah masalah yang umum dijumpai pada Andisol yang dapat menyebabkan ketersediaan $\mathrm{P}$ bagi tanaman menjadi rendah (Nurmaya et al., 2013). Ketersediaan P sangat menentukan produksi kopi arabika (Melke dan Ittana, 2015). Salah satu cara meningkatkan ketersediaan $\mathrm{P}$ dalam tanah dengan pemberian mikoriza dapat meningkatkan kandungan unsur hara P pada tanaman kopi (Hifnalisa et al., 2017).

Mikoriza terdiri dari dua kata yang berasal dari bahasa Yunani, yaitu mykes (fungi) dan rhiza (akar) (Brundrett et al., 2008). Fungi mikoriza arbuskula (FMA) adalah tipe asosiasi mikoriza yang tersebar sangat luas, fungi ini yang memiliki peran dan manfaat yang penting dalam dunia pertanian. Keberadaan FMA dapat meningkatkan serapan hara seperti N, P, K, serapan air, dan daya tahan tanaman terhadap kekeringan (Smith dan Read, 2008). FMA juga dapat melindungi tanaman yang hidup pada tanah yang tidak baik seperti tanah yang tercemar minyak bumi, cekaman air, $\mathrm{pH}$ rendah, dan logam berat merupakan peran dari mikoriza (Rizka et al., 2013).

Penyebaran dan keanekaragaman mikoriza sangat bervariasi, penyebab perbedaan keanekaragaman spesies dan populasi FMA salah satunya dikarenakan adanya perbedaan lokasi dan rizosfer, selain itu semua FMA tidak mempunyai sifat morfologi dan fisiologi yang sama, oleh karena itu sangat penting untuk mengetahui identitasnya (Hartoyo et al., 2011).

Informasi mengenai FMA pada tanaman kopi arabika di Kecamatan Timang Gajah, sampai saat ini belum ada dilaporkan. Mengingat manfaat FMA yang dapat meningkatkan pertumbuhan dan produktivitas tanaman, maka dari itu peneliti ingin mengetahui keberadaan FMA pada tanaman kopi arabika di lokasi tersebut. Eksplorasi FMA pada rizosfer tanaman kopi arabika merupakan studi awal yang penting dan perlu dilakukan untuk dapat mengidentifikasi jenis-jenis FMA yang dominan dan spesifik. Penelitian ini sangat penting untuk mendapatkan informasi tentang keanekaragaman jenis-jenis FMA yang potensial sebagai sumber bahan penting untuk seleksi memperoleh isolat FMA potensial dan efektif, serta, mampu beradaptasi pada lahan dan komoditas yang spesifik.

\section{METODE PENELITIAN}

Eksplorasi spora FMA dilaksanakan dengan mengambil sampel tanah di rizosfer perkebunan kopi rakyat di Desa Lampahan Barat dan Desa Mude Benara, Kecamatan Timang Gajah, Kabupaten Bener Meriah. Isolasi spora dan kolonisasi FMA dilakukan di Laboratorium Biologi Tanah Fakultas Pertanian Universitas Syiah Kuala. Analisis sifat fisika dan kimia tanah dilakukan di Laboratorium Departemen Ilmu Tanah dan Sumberdaya Lahan Fakultas Pertanian Institut Pertanian Bogor. Penelitian di laksanakan sejak Juli 2019 sampai Maret 2020.

\section{MATERI DAN METODE}

Penelitian ini menggunakan alat-alat berupa cangkul, pisau, kamera, mikroskop stereo, mikroskop compound, timbangan analitik, pinset spora, sentrifus, satu set saringan (ukuran $600 \mu \mathrm{m}, 160 \mu \mathrm{m}, 53 \mu \mathrm{m}$ dan $45 \mu \mathrm{m}$ ), botol film, kertas label dan alat-alat gelas yang diperlukan untuk analisis di laboratorium. Penelitian ini menggunakan bahan berupa sampel tanah, air destilata, cuka komersial 5\%, sukrosa $60 \%, \mathrm{KOH} \mathrm{10 \% ,} \mathrm{tinta} \mathrm{parker} \mathrm{biru,} \mathrm{larutan}$ PVLG (Polyvinyl Lacto Glycerol). 


\section{Metode Penelitian}

Penelitian ini menggunakan metode survei, dengan cara mengambil sampel tanah secara langsung dari lapangan yaitu pada rizosfer tanaman kopi arabika varietas Gayo 1, Gayo 2, Ateng Super, dan Tim-Tim. Masing-masing varietas dan umur (tiga dan lima tahun) diambil sebanyak 3 titik, sehingga didapatkan sebanyak 24 sampel (Tabel 1). Sampel tanah tersebut digunakan untuk mengisolasi jenis FMA yang terdapat di lahan tersebut. Analisis beberapa sifat kimia dan fisika juga dilakukan untuk mendapatkan data pendukung. Aspek dan metode analisis beberapa sifat tanah berupa $\mathrm{pH} \mathrm{H} 2 \mathrm{O}$, C-Organik, N-Total, P-Tersedia, KTK dan Tekstur. Data yang diperoleh dianalisis secara deskriptif.

\section{Prosedur Kerja}

\section{Pengambilan Sampel Tanah}

Titik lokasi pengambilan sampel tanah pada tanaman kopi arabika. Sampel tanah diambil pada rizosfer tanaman kopi arabika sebanyak $1 \mathrm{~kg}$ pada kedalaman $0-30 \mathrm{~cm}$. Sampel tanah tersebut dimasukkan ke dalam plastik kemudian diberi keterangan lokasi pengambilan dan tanggal pengambilan.

Tabel 1. Titik lokasi pengambilan sampel tanah pada tanaman kopi arabika.

\begin{tabular}{|c|c|c|c|c|c|}
\hline Varietas & Umur & Nama lokasi & Titik & & Titik Koordinat \\
\hline \multirow{6}{*}{ Gayo 1} & \multirow{3}{*}{3 Tahun } & \multirow{3}{*}{ Lampahan Barat } & 1 & $\mathrm{~N} \mathrm{04} 45^{\prime} 59,18^{\prime \prime}$ & E $096^{\circ} 44^{\prime} 28,13^{\prime \prime}$ \\
\hline & & & 2 & N 044' $59,07^{\prime \prime}$ & E $096^{\circ} 44^{\prime} 28,01^{\prime \prime}$ \\
\hline & & & 3 & $\mathrm{~N} 04^{\circ} 45^{\prime} 58,62^{\prime \prime}$ & E $096^{\circ} 44^{\prime} 27,64^{\prime \prime}$ \\
\hline & \multirow{3}{*}{5 Tahun } & \multirow{3}{*}{ Lampahan Barat } & 1 & 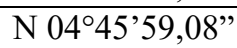 & E 09644’27,64” \\
\hline & & & 2 & N $04^{\circ} 45^{\prime} 58,46^{\prime \prime}$ & E $096^{\circ} 44^{\prime} 28,10^{\prime \prime}$ \\
\hline & & & 3 & N $04^{\circ} 45^{\prime} 57,88^{\prime \prime}$ & E $096^{\circ} 44^{\prime} 27,88^{\prime \prime}$ \\
\hline \multirow{6}{*}{ Gayo 2} & \multirow{3}{*}{3 Tahun } & \multirow{3}{*}{ Lampahan Barat } & 1 & $\mathrm{~N} 04^{\circ} 45^{\prime} 59,75^{\prime \prime}$ & E 09644'28,14" \\
\hline & & & 2 & $\mathrm{~N} 04^{\circ} 45^{\prime} 59,56^{\prime \prime}$ & E $096^{\circ} 44^{\prime} 28,18^{\prime \prime}$ \\
\hline & & & 3 & N 04⒋ $45^{\prime} 59,13^{\prime \prime}$ & E $096^{\circ} 44^{\prime} 28,13^{\prime \prime}$ \\
\hline & \multirow{3}{*}{5 Tahun } & \multirow{3}{*}{ Lampahan Barat } & 1 & $\mathrm{~N} \mathrm{04} 45^{\prime} 57,72^{\prime \prime}$ & E 09644'28,04" \\
\hline & & & 2 & N 044ㄴ $57,09^{\prime \prime}$ & E $096^{\circ} 44^{\prime} 28,34^{\prime \prime}$ \\
\hline & & & 3 & 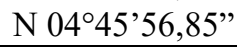 & E $096^{\circ} 44^{\prime} 28,05^{\prime \prime}$ \\
\hline \multirow{6}{*}{ Ateng Super } & \multirow{3}{*}{3 Tahun } & \multirow{3}{*}{ Lampahan Barat } & 1 & 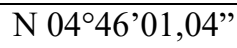 & E 09644’29,89' \\
\hline & & & 2 & N 044ㅇ' $01,43^{\prime \prime}$ & E $096^{\circ} 44^{\prime} 29,81^{\prime \prime}$ \\
\hline & & & 3 & N 044ㅇ'01,80" & E $096^{\circ} 44^{\prime} 29,84^{\prime \prime}$ \\
\hline & \multirow{3}{*}{5 Tahun } & \multirow{3}{*}{ Mude Benara } & 1 & N 044ㄴ'45, $8^{\prime \prime}$ & E 09646’18,7’' \\
\hline & & & 2 & $\mathrm{~N} 04^{\circ} 44^{\prime} 46,1^{\prime \prime}$ & E $096^{\circ} 46^{\prime} 19,5^{\prime \prime}$ \\
\hline & & & 3 & $\mathrm{~N} 04^{\circ} 44^{\prime} 46,0^{\prime \prime}$ & E 096 $46^{\prime} 20,5^{\prime \prime}$ \\
\hline \multirow{6}{*}{ Tim-Tim } & \multirow{3}{*}{3 Tahun } & \multirow{3}{*}{ Mude Benara } & 1 & N 0444'45,3”' & E 09646’18,6" \\
\hline & & & 2 & N $04^{\circ} 44^{\prime} 46,6^{\prime \prime}$ & Е 09646'17,9”' \\
\hline & & & 3 & N $04^{\circ} 44^{\prime} 46,8^{\prime \prime}$ & E $096^{\circ} 46^{\prime} 18,8^{\prime \prime}$ \\
\hline & \multirow{3}{*}{5 Tahun } & \multirow{3}{*}{ Lampahan Barat } & 1 & 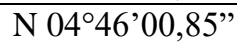 & E 09644'29,01" \\
\hline & & & 2 & N 044ㅇ'00,94" & E $096^{\circ} 44^{\prime} 29,27^{\prime \prime}$ \\
\hline & & & 3 & 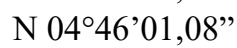 & Е $096^{\circ} 44^{\prime} 28,85^{\prime \prime}$ \\
\hline
\end{tabular}

\section{Jumlah Spora FMA}

Jumlah spora FMA didapatkan dengan cara mengisolasi menggunakan teknik penyaringan basah dan dilanjutkan dengan teknik sentrifugasi (Brundrett et al., 1996). Sampel media masing-masing perlakuan sebanyak $50 \mathrm{~g}$ dimasukkan ke dalam gelas beaker dan dilarutkan $500 \mathrm{ml}$ air, kemudian diaduk hingga homogen dan didiamkan selama 30 menit. Suspensi media dituangkan ke dalam saringan mikro berukuran $600 \mu \mathrm{m}, 160 \mu \mathrm{m}, 53 \mu \mathrm{m}$ dan $45 \mu \mathrm{m}$ yang disusun secara bertingkat dengan ukuran yang paling besar berada paling atas. 
Kemudian dicuci dengan air keran hingga air jernih. Hasil penyaringan masing-masing saringan $(160 \mu \mathrm{m}, 53 \mu \mathrm{m}$ dan $45 \mu \mathrm{m})$ dipindahkan ke dalam tabung sentrifus sebanyak $100 \mathrm{ml}$ dan disentrifus selama 3 menit dengan kecepatan $2500 \mathrm{rpm}$. Hasil saringan dalam tabung sentrifuse ditambahkan dengan sukrosa $60 \%$ yang diletakkan pada bagian bawah larutan menggunakan pipet. Tabung sentrifuse ditutup rapat dan disentrifugasi dengan kecepatan $2500 \mathrm{rpm}$ selama 30 detik. Supernatan yang mengandung spora ditampung pada saringan berukuran $45 \mu \mathrm{m}$ dan dicuci sampai bersih. Selanjutnya spora tersebut dikumpulkan dan dihitung jumlahnya secara manual dengan menggunakan mikroskop stereo. Pengamatan jumlah spora menggunakan mikroskop stereo untuk menghitung jumlah populasi spora per sampel tanah.

\section{Identifikasi Jenis Spora FMA}

Identifikasi genus dilakukan dengan pembuatan preparat. Spora ditetesi larutan PVLG selanjutnya spora-spora tersebut diamati morfologinya di bawah mikroskop compound. Karakter morfologi spora mikoriza yang diamati meliputi: bentuk spora, ukuran spora, warna spora, hifa attachment dan ornament spora. Keanekaragaman spora dihitung menggunakan rumus frekuensi relatif (Shi et al., 2007):

$$
\mathrm{F}(100 \%)=\frac{\sum \text { spora per genus }}{\text { total spora }} \times 100 \%
$$

Keterangan: Fr $=$ Frekuensi relatif

\section{Kolonisasi FMA}

Kolonisasi FMA dapat diamamati dengan teknik pewarnaan akar (staining) dengan metode Brundrett et al. (1996). Cara kerja pewarnaan akar dimulai dari memotong lebih kurang $\pm 2 \mathrm{~cm}$ kemudian dicuci dengan air mengalir hingga bersih. Akar sampel dimasukkan ke dalam larutan $\mathrm{KOH} 10 \%$ panas (suhu minimum $90^{\circ} \mathrm{C}$ ) selama 30 menit. Selanjutnya larutan $\mathrm{KOH}$ dibuang dan akar sampel dicuci dengan air mengalir selama 2-5 menit. Selanjutnya akar sampel direndam dalam larutan tinta-cuka 5\% dan direndam selama kurang lebih 24 jam. Akar dipotong lebih kurang $\pm 1 \mathrm{~cm}$ dan disusun sebanyak 10 buah pada gelas preparat kemudian tutup dengan kaca penutup. Akar diamati dengan mikroskop cahaya untuk dilihat struktur mikorizanya (hifa, spora, arbuskula, vesikula) dan diberi tanda (+). Perhitungan kolonisasi akar oleh FMA menggunakan metode panjang akar terkolonisasi (Brundrett et al., 1996) menggunakan rumus:

$$
\text { Persentase akar yang terinfeksi }=\frac{\Sigma \text { bidang pandang akar bermikoriza }}{\Sigma \text { bidang pandang yang diamati }} \times 100 \%
$$

Kolonisasi FMA akar tanaman dapat dikategorikan dalam lima kelas menurut Rajapakse dan Miller (1992). Kategori tingkat kolonisasi FMA dapat dilihat pada Tabel 2. 
Tabel 2. Tingkat kolonisasi FMA

\begin{tabular}{cll}
\hline Persentase kolonisasi & Kategori & Keterangan \\
\hline $0-5$ & Kelas 1 & Sangat rendah \\
$6-25$ & Kelas 2 & Rendah \\
$26-50$ & Kelas 3 & Sedang \\
$51-75$ & Kelas 4 & Tinggi \\
$76-100$ & Kelas 5 & Sangat tinggi \\
\hline
\end{tabular}

Sumber: Rajapakse dan Miller (1992)

\section{Analisis Data}

Hasil pengamatan dianalisis secara deskriptif dalam bentuk tabel dengan menyajikan Kepadatan spora, keanekaragaman spora dan persentase akar terkoloni FMA.

\section{HASIL DAN PEMBAHASAN}

\section{Hasil Analisis Sifat Tanah}

Hasil analisis beberapa sifat tanah di lokasi pengambilan sampel pada beberapa varietas dan umur kopi arabika di Kecamatan Timang Gajah dapat dilihat pada Tabel 3.

Tabel 3. Hasil analisis sifat kimia tanah pada beberapa varietas dan umur kopi arabika di Kecamatan Timang Gajah.

\begin{tabular}{|c|c|c|c|c|c|c|c|c|}
\hline \multirow[b]{2}{*}{ Sifat Kimia Tanah } & \multicolumn{2}{|c|}{ Gayo 1} & \multicolumn{2}{|c|}{ Gayo 2} & \multicolumn{2}{|c|}{ Ateng Super } & \multicolumn{2}{|c|}{ Tim-Tim } \\
\hline & $\begin{array}{c}3 \\
\text { Tahun }\end{array}$ & $\begin{array}{c}5 \\
\text { Tahun } \\
\end{array}$ & $\begin{array}{c}3 \\
\text { Tahun }\end{array}$ & $\begin{array}{c}5 \\
\text { Tahun } \\
\end{array}$ & $\begin{array}{c}3 \\
\text { Tahun }\end{array}$ & $\begin{array}{c}5 \\
\text { Tahun }\end{array}$ & $\begin{array}{c}3 \\
\text { Tahun }\end{array}$ & $\begin{array}{c}5 \\
\text { Tahun } \\
\end{array}$ \\
\hline $\mathrm{pH}\left(\mathrm{H}_{2} \mathrm{O}\right)$ & $5,09^{\mathrm{M}}$ & $5,13^{\mathrm{M}}$ & $5,19^{\mathrm{M}}$ & $5,26^{\mathrm{M}}$ & $4,20^{\mathrm{SM}}$ & $4,70^{\mathrm{M}}$ & $5,27^{\mathrm{M}}$ & $5,08^{\mathrm{M}}$ \\
\hline C-Organik (\%) & $6,11^{\mathrm{ST}}$ & $5,82^{\mathrm{ST}}$ & $5,82^{\mathrm{ST}}$ & $5,76^{\mathrm{ST}}$ & $5,60^{\mathrm{ST}}$ & $2,58^{\mathrm{S}}$ & $3,76^{\mathrm{T}}$ & $6,06^{\mathrm{ST}}$ \\
\hline N-Total (\%) & $0,51^{\mathrm{T}}$ & $0,48^{\mathrm{S}}$ & $0,51^{\mathrm{T}}$ & $0,43^{S}$ & $0,44^{\mathrm{s}}$ & $0,32^{\mathrm{S}}$ & $0,50^{\mathrm{S}}$ & $0,53^{\mathrm{T}}$ \\
\hline P-Tersedia (ppm) & $13,55^{\mathrm{R}}$ & $9,03^{\mathrm{SR}}$ & $10,76^{\mathrm{R}}$ & $8,48^{\mathrm{SR}}$ & $4,60^{\mathrm{SR}}$ & $349,44^{\mathrm{ST}}$ & $111,21^{\mathrm{ST}}$ & $16,37^{\mathrm{S}}$ \\
\hline $\operatorname{KTK}\left(\mathrm{cmol} \mathrm{Kg}{ }^{-1}\right)$ & $23,94^{\mathrm{S}}$ & $24,85^{\mathrm{S}}$ & $24,08^{\mathrm{S}}$ & $19,37^{\mathrm{S}}$ & $19,37^{\mathrm{S}}$ & $14,67^{\mathrm{R}}$ & $15,98^{\mathrm{R}}$ & $22,37^{\mathrm{S}}$ \\
\hline Tekstur & LB & LB & LB & LB & LB & PB & PB & LB \\
\hline
\end{tabular}

Hasil analisis $\mathrm{pH}$ tanah di rizosfer pada beberapa varietas dan umur kopi arabika di Kecamatan Timang Gajah menunjukkan bahwa pH berkisar 4,20-5,27 (sangat masam-masam) berdasarkan kriteria sifat kimia tanah (LPT, 1983). pH tanah terendah 4,20 dijumpai pada tanaman kopi arabika varietas Ateng Super umur 3 tahun. Rendahnya pH tanah ini diduga dipengaruhi oleh jenis tanah dan curah hujan di lokasi tersebut. Lokasi pada penelitian memiliki jenis tanah ordo Andisol (Manfarizah et al., 2011) yang mengandung fraksi pasir yang tinggi menyebabkan kemampuan tanah dalam memegang unsur hara menjadi lebih kecil sehingga mudah hilang dan menyebabkan penurunan nilai $\mathrm{pH}$ tanah. Hal ini sejalan dengan pernyataan Juarti, (2016) yang mengemukakan $\mathrm{pH}$ tanah tersebut dipengaruhi fraksi pasir yang tinggi mengakibatkan kemampuan tanah memegang unsur hara dan kation-kation basa yang lebih kecil mudah hilang terbawa air perkolasi dan menyebabkan penurunan nilai $\mathrm{pH}$. Curah hujan yang tinggi (1,700 - 2,500 mm Abubakar et al., 2018) diduga menyebabkan $\mathrm{pH}$ menjadi masam dikarenakan terjadinya pencucian unsur hara serta kation-kation basa.

C-organik tanah dilokasi pengambilan sampel pada beberapa varietas dan umur kopi arabika di Kecamatan Timang Gajah memiliki kisaran 2,58\% - 6,11\% yang tergolong sedang hingga sangat tinggi. C-organik terendah terdapat pada rizosfer tanaman kopi arabika varietas 
Ateng Super umur 5 tahun sebesar 2,58\% yang tergolong sedang, kriteria sifat tanah menurut (LPT, 1983). C-organik yang sangat tinggi pada beberapa lokasi penelitian diduga terjadi akibat adanya pembentukan kompleks alofan-humus menjadikan humus sangat tahan terhadap dekompsisi, akibatnya waktu tinggal rata-rata C-organik menjadi jauh lebih lama. Pernyataan di atas sesuai dengan pendapat Sukarman dan Dariah, (2014) bahwa humus akan terus terakumulasi sebagai hasil pelapukan yang terikat oleh alofan yang mengandung Al untuk membuat kompleks Al-humus yang tahan terhadap dekomposisi. C-organik yang sangat tinggi juga diduga akibat adanya penimbunan serasah-serasah dari tanaman kopi arabika yang terdekomposisi dan menjadi pupuk organik serta banyaknya daun kopi maupun daun tanaman yang gugur diatas permukaan tanah dapat memberikan masukan sebagai pupuk organik tanah. Bahan organik adalah bahan-bahan yang dapat diperbaharui, dirombak oleh bakteri-bakteri tanah menjadi, didaur ulang, unsur yang dapat dimanfaatkan oleh tanaman tanpa mencemari tanah dan air (Hanafiah, 2005).

Hasil analisis N-total pada lokasi pengambilan sampel pada beberapa varietas dan umur kopi arabika di Kecamatan Timang Gajah menjukan bahwa berkisar 0,32\% - 0,53\% yang tergolong sedang hingga tinggi. Nilai N-Total yang tergolong sedang pada beberapa titik lokasi penelitian diduga di pengaruhi oleh $\mathrm{C}$-organik yang tergolong sedang juga. Hal ini sejalan dengan pernyataan Hasanuddin, 2003 yang mengemukakan umumnya N-total yang ada didalam tanah tinggi apabila jumlah bahan organik juga tinggi karena terjadinya dekomposisi bahan organik yang akan terurai menjadi nitrat $\left(\mathrm{NO}_{3}^{-}\right)$atau ammonium $\left(\mathrm{NH}_{4}^{+}\right)$. Kekurangan $\mathrm{N}$ bagi tanaman dapat mempengaruhi pertumbuhan tanaman seperti daun tanaman menguning, pertumbuhan tanaman kerdil, dan sistem perakaran tanaman terbatas (Kaya, 2013).

Unsur hara P-tersedia pada lokasi pengambilan sampel pada beberapa varietas dan umur kopi arabika di Kecamatan Timang Gajah berkisar 4,60 ppm - 349,44 ppm yang termasuk kedalam kriteria sangat rendah hingga sangat tinggi. Tabel 3 menunjukan hasil nilai P-tersedia tergolong sangat rendah pada kopi arabika varietas Gayo 1 dan Gayo 2 umur lima tahun serta Ateng Super umur tiga tahun, kriteria rendah terdapat pada kopi arabika varietas Gayo 1 dan Gayo 2 umur tiga tahun, kriteria sedang terdapat pada kopi arabika varietas Tim-Tim umur lima tahun, Kriteria sangat tinggi terdapat pada kopi arabika varietas Tim-Tim umur tiga tahun dan Ateng super umur lima tahun, kriteria penilaian sifat kimia tanah menurut (LPT, 1983). P-tersedia yang rendah diduga akibat adanya mineral alofan pada Andisol yang mampu mengikat unsur hara $\mathrm{P}$ menjadi tidak tersedia bagi tanaman. Hal ini sejalan dengan pernyatan Zurhalena dan Endriyani, (2004), adanya senyawa aktif Al dan Fe di dalam tanah mengakibatkan $\mathrm{P}$ terjerap kuat pada struktur mineral amorf, hal ini menunjukkan bahwa alofan sangat kuat mengikat $\mathrm{P}$ dari pada dengan kemampuan asam-asam organik dalam melepaskan $\mathrm{P}$ dari jerapan. P-Tersedia yang sangat tinggi terdapat pada kopi arabika varietas Tim-Tim umur tiga tahun dan Ateng super umur 5 tahun diduga akibat adanya pemupukan yang intensif.

Tabel 3 menunjukkan bahwa nilai KTK tanah berkisar antara 14,67-24,85 $\mathrm{cmol} \mathrm{Kg}^{-1}$ yang termasuk kedalam kriteria rendah hingga sedang. Hasil analisis yang tergolong rendah terdapat pada kopi arabika varietas Ateng Super umur lima tahun dan varietas Tim-Tim umur tiga tahun, kriteria penilaian sifat kimia tanah menurut (LPT, 1983). Kapasitas tukar kation (KTK) tanah ialah jumlah total kation yang bisa dipertukarkan dari suatu tanah baik kation pada koloid organik (humus) maupun kation pada permukaan koloid anorganik (liat) (Madjid, 2007). KTK tanah yang sedang hingga rendah di lokasi tersebut diduga dipengaruhi oleh $\mathrm{pH}$ yang masam. Hal ini sejalan dengan pendapat Sudaryono, (2009) menyatakan bahwa rendahnya KTK tanah secara langsung dan tidak langsung dipengaruhi oleh reaksi tanah yang 
sangat masam. Hal lain yang mempengaruhi nilai KTK tanah rendah yaitu tekstur tanah yang banyak mengandung pasir, seperti hasil analisis tekstur tanah pada sampel tanah yang diamati menunjukkan pasir berlempung dan lempung berpasir diduga dapat menyebabkan unsur hara tercuci. Hal ini dikarenakan tekstur tanah yang kasar menyebabkan daya jerap lebih mudah lepas atau hilang sehingga mudah sekali tercuci (Mukhlis, 2007).

Pengambilan sampel pada lokasi beberapa varietas dan umur kopi arabika di Kecamatan Timang Gajah yang diamati terdapat pada Tabel 3 termasuk kedalam tekstur tanah lempung berpasir pada kopi arabika varietas Gayo 1, Gayo 2, Ateng Super umur tiga tahun dan, TimTim umur lima tahun. Sampel tanah pada kopi arabika varietas Ateng Super umur lima tahun dan Tim-Tim umur tiga tahun memiliki tekstur tanah pasir berlempung. Hasil analisis dari semua titik menunjukan kandungan fraksi pasir yang tinggi berkisar $(56,31 \%-74,66 \%)$ dari pada fraksi debu berkisar $(19,60 \%$ - 34,72 \%) dan liat berkisar $(5,75 \%-9,81 \%)$. Menurut Dariah et al. (2003) pada tanah yang banyak fraksi pasir akan mengalirkan air yang lebih cepat dibandingkan dengan tanah-tanah berfraksi debu dan liat. Hal ini diduga karena ukuran fraksi pasir yang kasar. Fraksi pasir yang kasar menyebabkan terjadinya pencucian unsur hara yang ukurannya lebih kecil sehingga diduga menyebabkan $\mathrm{pH}$ menjadi sangat masam hingga masam.

\section{Kepadatan Spora}

Spora ialah salah satu bentuk untuk pertahanan hidup di alam yang berfungsi sebagai proses adaptasi terutama apabila mikoriza tersebut belum menemukan tanaman inang yang kompatibel (Smith dan Read, 2008). Tabel rata-rata jumlah kepadatan spora pada beberapa varietas dan umur kopi arabika di Kecamatan Timang Gajah per $50 \mathrm{~g}$ tanah dapat dilihat pada Tabel 4.

Tabel 4. Rata-rata jumlah kepadatan spora FMA (per $50 \mathrm{~g}$ tanah) pada berbagai varietas dan umur kopi arabika di Kecamatan Timang Gajah.

\begin{tabular}{|c|c|c|c|c|c|c|}
\hline \multirow{2}{*}{ Varietas } & \multirow{2}{*}{ Umur } & \multicolumn{3}{|c|}{ Ulangan } & \multirow{2}{*}{ Jumlah } & \multirow{2}{*}{ Rata-rata } \\
\hline & & 1 & 2 & 3 & & \\
\hline \multirow{2}{*}{ Gayo 1} & 3 Tahun & 132 & 48 & 14 & 194 & 65 \\
\hline & 5 Tahun & 18 & 39 & 45 & 102 & 34 \\
\hline \multirow{2}{*}{ Gayo 2} & 3 Tahun & 87 & 16 & 9 & 112 & 37 \\
\hline & 5 Tahun & 32 & 36 & 55 & 123 & 41 \\
\hline \multirow{2}{*}{ Ateng Super } & 3 Tahun & 17 & 30 & 47 & 94 & 31 \\
\hline & 5 Tahun & 2 & 9 & 11 & 22 & 7 \\
\hline \multirow{2}{*}{ Tim-Tim } & 3 Tahun & 6 & 5 & 12 & 23 & 8 \\
\hline & 5 Tahun & 573 & 471 & 284 & 1328 & 443 \\
\hline
\end{tabular}

Tabel 4 menunjukan rata-rata kepadatan spora FMA paling sedikit ditemukan pada rizosfer tanaman kopi arabika varietas Ateng Super berumur lima tahun yaitu dengan rata-rata sebanyak tujuh spora per $50 \mathrm{~g}$ tanah. Jumlah rata-rata kepadatan spora FMA terbanyak ditemukan pada rizosfer tanaman kopi arabika varietas Tim-Tim berumur lima tahun yaitu dengan rata-rata sebanyak 443 spora per $50 \mathrm{~g}$ tanah.

Kepadatan spora diduga sangat dipengaruhi oleh unsur hara $\mathrm{P}$, semakin tinggi ketersediaan unsur $\mathrm{P}$ maka semakin rendah kepadatan spora. Pernyataan tersebut sesuai dengan hasil penelitian pada Tabel 3 yang dilakukan pada tanaman kopi arabika varietas 
Ateng Super umur lima tahun dan varietas Tim-Tim umur 3 tahun, menunjukkan bahwa pada kedua varietas tersebut memiliki hasil P-tersedia yang sangat tinggi tetapi kepadatan sporanya rendah. Hal ini sesuai dengan Yusriadi et al. (2018) bahwa kandungan hara khususnya P, fungi mikoriza menjadi tidak berkembang dengan baik apabila kondisi tingkat kesuburan tanah yang baik, terutama dengan kandungan $\mathrm{P}$ tersedia semakin tinggi.

C-organik merupakan salah satu faktor lainnya yang mempengaruhi tinggi rendahnya jumlah populasi spora, Menurut Madjid (2007) C-organik yang tinggi menyebabkan jumlah spora yang ditemukan tinggi. Hal ini menunjukan hal yang sama dengan hasil penelitian dengan jumlah spora yang paling sedikit ditemukan pada tanah yang kandungan C-organiknya tergolong sedang 2,58 \% (Tabel 3) terdapat pada tanaman kopi arabika varietas Ateng Super umur 5 tahun sebanyak 22 spora per 50 g tanah (Tabel 5). Sedangkan kandungan C-organik yang tergolong sangat tinggi (Tabel 3) pada varietas Tim-Tim umur 5 tahun menujukan jumlah spora yang terbanayak juga sebanyak 1328 spora per $50 \mathrm{~g}$ tanah (Tabel 4).

KTK tanah yang tinggi diduga dapat mempengaruhi kepadatan spora FMA, KTK yang tinggi salah satu syarat untuk pertumbuhan FMA lebih baik. Sependapat dengan pernyataan Usnawiyah dan Khaidir, (2013) menyatakan bahwa media tumbuh mikoriza memiliki syarat antara lain; berpasir dengan kapasitas tukar kation (KTK) yang tinggi, tekstur yang kasar, dan $\mathrm{P}$ yang tergolong rendah. Hal ini sesuai denga hasil penelitian bahwa nilai KTK tanah yang rendah pada tanaman kopi arabika varietas Ateng Super umur lima tahun dan varietas TimTim umur tiga tahun, menunjukan bahwa KTK yang rendah dikuti dengan rendahnya kepadatan spora FMA.

\section{Keanekaragaman FMA}

Hasil isolasi, pengamatan dan identifikasi morfologis yang dilakukan didapatkan tiga genus spora FMA yaitu Acaulospora, Gigaspora, dan, Glomus. Karakteristik dan tipe spora yang didapatkan mempunyai berbagai perbedaan mulai dari bentuk, warna, maupun ukuran. Hasil identifikasi FMA yang berhasil diidentifikasi di rizosfer pada berbagai varietas dan umur kopi arabika di Kecamatan Timang Gajah dilihat pada Gambar berikut.
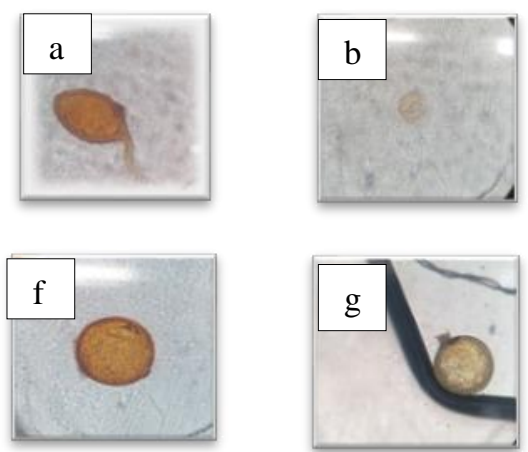
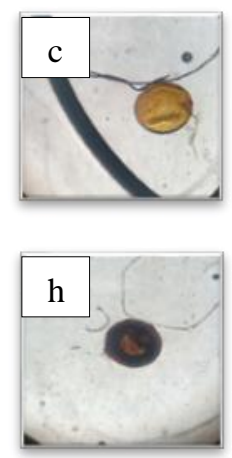
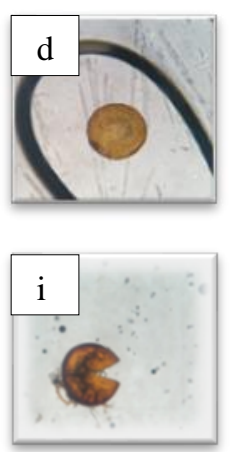
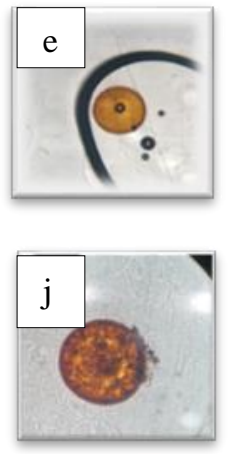

Gambar 1. a. Glomus sp.1, b. Glomus sp.2, c. Acaulospora sp.1, d. Acaulospora sp.2, e. Acaulospora sp.3, f. Acaulospora sp.4, g. Gigaspora sp.1,

h. Gigaspora sp.2, i. Gigaspora sp.3, j. Gigaspora sp.4. 
Tabel 5. Keanekaragaman spora pada berbagai varietas dan umur kopi arabika di Kecamatan Timang Gajah.

\begin{tabular}{|c|c|c|c|c|c|c|c|c|c|c|c|c|c|}
\hline \multirow[b]{2}{*}{ Varietas } & \multirow[b]{2}{*}{ Umur } & \multirow[b]{2}{*}{$\begin{array}{l}\text { Jumlah } \\
\text { Spesies }\end{array}$} & \multirow[b]{2}{*}{$\begin{array}{l}\text { Jumlah } \\
\text { Genus }\end{array}$} & \multicolumn{10}{|c|}{ Spesies FMA } \\
\hline & & & & $\begin{array}{l}\text { G } \\
\text { sp.1 }\end{array}$ & $\begin{array}{l}\mathrm{G} \\
\mathrm{sp} .2\end{array}$ & $\begin{array}{l}\text { Ac } \\
\text { sp.1 }\end{array}$ & $\begin{array}{l}\text { Ac } \\
\text { sp.2 }\end{array}$ & $\begin{array}{l}\text { Ac } \\
\text { sp. } 3\end{array}$ & $\begin{array}{l}\text { Ac } \\
\text { sp.4 }\end{array}$ & $\begin{array}{l}\mathrm{Gi} \\
\mathrm{sp} .1\end{array}$ & $\begin{array}{l}\mathrm{Gi} \\
\mathrm{sp} .2\end{array}$ & $\begin{array}{l}\mathrm{Gi} \\
\mathrm{sp} .3\end{array}$ & $\begin{array}{l}\mathrm{Gi} \\
\mathrm{sp} .4\end{array}$ \\
\hline Gayo 1 & 3 Tahun & 4 & 2 & 131 & 0 & 0 & 0 & 0 & 0 & 0 & 4 & 10 & 49 \\
\hline \multirow{2}{*}{ Gayo 2} & 3 Tahun & 4 & 2 & 100 & 0 & 0 & 0 & 0 & 0 & 0 & 5 & 1 & 6 \\
\hline & 5 Tahun & 3 & 2 & 98 & 0 & 0 & 0 & 0 & 0 & 0 & 11 & 0 & 14 \\
\hline \multirow{2}{*}{ Tim-Tim } & 3 Tahun & 5 & 3 & 4 & 0 & 3 & 0 & 12 & 1 & 3 & 0 & 0 & 0 \\
\hline & 5 Tahun & 5 & 3 & 344 & 289 & 0 & 0 & 54 & 638 & 0 & 0 & 3 & 0 \\
\hline
\end{tabular}

Keterangan: G: Glomus, Ac: Acaulospora, Gi: Gigaspora, sp: Spesies

Tabel 5 menunjukkan bahwa pada rizosfer kopi arabika umur 3 tahun terdapat satu spesies Glomus dan tiga spesies Gigaspora pada rizosfer kopi arabika varietas Gayo 1, Gayo 2 dan Ateng Super. Terdapat satu spesies Glomus, tiga spesies Acaulospora, dan satu spesies Gigaspora pada rizosfer kopi arabika varietas Tim-Tim. Pada rizosfer kopi arabika umur lima tahun menunjukkan bahwa terdapat satu spesies Glomus dan dua spesies Gigaspora pada rizosfer kopi arabika varietas Gayo 1 dan Gayo 2. Terdapat satu spesies Glomus, tiga spesies Acaulospora, dan dua spesies Gigaspora pada rizosfer kopi arabika varietas Ateng Super. Terdapat dua spesies Glomus, dua spesies Acaulospora, dan satu spesies Gigaspora pada rizosfer kopi arabika varietas Tim-Tim. Keanekaragaman FMA pada lokasi penelitian dapat dilihat dengan adanya perbedaan jumlah populasi dan komposisi genus FMA (Sri dan Agustina, 2016).

Perbedaan lokasi dan rizosfer tanaman kopi arabika diduga menyebabkan perbedaan keanekaragaman spesies dan populasi FMA, dimana pada lokasi dan rizosfer yang memiliki tanah yang bertekstur lempung dan berpasir memiliki kesesuaian perkembangan spora yang beda. Saputra et al. (2015) menyatakan bahwa jumlah spora jamur FMA yang paling banyak ditemukan adalah jenis Glomus, hasil tersebut menunjukkan jenis mikoriza Glomus mempunyai adaptasi yang baik terhadap berbagai jenis lingkungan dibandingkan dengan jenis FMA lainnya.

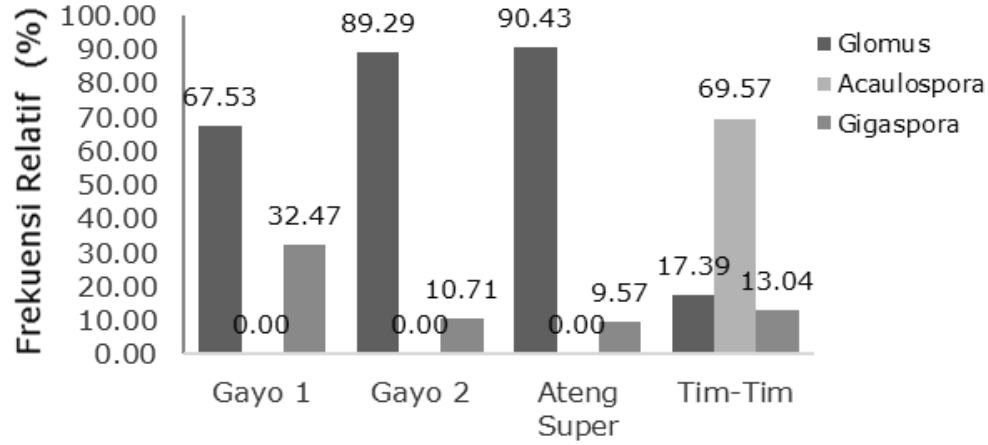

Gambar 2. Frekuensi relatif genus FMA pada berbagai varietas dan umur kopi arabika umur 3 tahun di Kecamatan Timang Gajah.

Gambar 2 dan Gambar 3 menunjukkan bahwa Glomus memiliki sebaran rata-rata yang dominan tinggi di setiap lokasi pengambilan sampel. Frekuensi relatif yang tertinggi pada Glomus terdapat pada rizosfer tanaman kopi arabika umur 3 tahun varietas Gayo $1(67,53 \%)$, varietas Gayo 2 (89,29\%), dan varietas Ateng Super (90.43\%). Pada rizosfer tanaman kopi 
arabika umur 5 tahun frekuensi relatif Glomus yang dominan terdapat pada varietas Gayo 1 $(61,76 \%)$, dan varietas Gayo $2(79,67 \%)$.

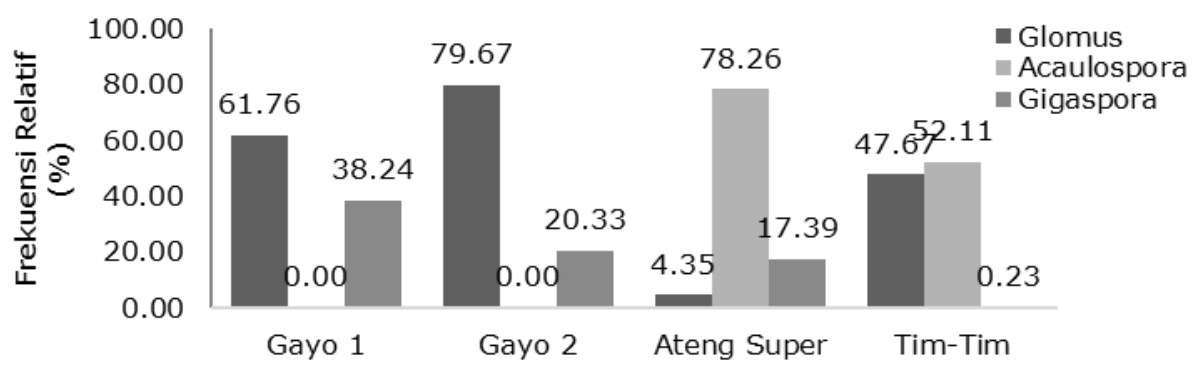

Gambar 3. Frekuensi relatif Genus FMA pada berbagai varietas dan umur kopi arabika umur 5 tahun di Kecamatan Timang Gajah.

Berdasarkan hasil yang didapatkan, bahwa pada lokasi pengambilan sampel yang berbeda dijumpai juga jumlah populasi dan komposisi FMA yang berbeda pula. Pada rizosfer tanaman kopi arabika umur tiga tahun varietas Gayo 1, varietas Gayo 2, varietas Ateng Super dan tanaman kopi arabika umur lima tahun varietas Gayo 1, dan varietas Gayo 2, hanya ditemukan genus Gigaspora dan Glomus. Tetapi untuk genus Acouluspora dapat ditemukan pada rizosfer tanaman kopi arabika varietas Tim-Tim umur tiga tahun dan varietas Ateng Super dan Tim-Tim umur lima tahun. Genus Glomus dapat menyebar pada setiap pengambilan sampel. Adanya keanekaragaman FMA pada lokasi penelitian ditandai dengan adanya perbedaan jumlah populasi dan komposisi genus FMA.

\section{Kolonisasi FMA}

Hasil pengamatan persentase kolonisasi FMA pada beberapa varietas dan umur kopi arabika di Kecamatan Timang Gajah terdapat pada Tabel 7.

Tabel 6. Persentase kolonisasi FMA pada beberapa varietas dan umur kopi arabika di Kecamatan Timang Gajah.

\begin{tabular}{|c|c|c|c|c|c|c|}
\hline \multirow{2}{*}{ Varietas } & \multirow{2}{*}{ Umur } & \multicolumn{3}{|c|}{ Ulangan } & \multirow{2}{*}{ Rata-rata } & \multirow{2}{*}{ Keterangan } \\
\hline & & 1 & 2 & 3 & & \\
\hline \multirow{2}{*}{ Gayo 1} & 3 Tahun & 7 & 6 & 1 & 5 & Sangat Rendah \\
\hline & 5 Tahun & 1 & 1 & 1 & 1 & Sangat Rendah \\
\hline Total & & 8 & 7 & 2 & & \\
\hline \multirow{2}{*}{ Gayo 2} & 3 Tahun & 2 & 4 & 6 & 4 & Sangat Rendah \\
\hline & 5 Tahun & 1 & 1 & 1 & 1 & Sangat Rendah \\
\hline Total & & 3 & 5 & 7 & & \\
\hline \multirow{2}{*}{ Ateng Super } & 3 Tahun & 2 & 3 & 12 & 6 & Rendah \\
\hline & 5 Tahun & 1 & 4 & 2 & 2 & Sangat Rendah \\
\hline Total & & 3 & 7 & 14 & & \\
\hline \multirow{2}{*}{ Tim-Tim } & 3 Tahun & 6 & 10 & 6 & 7 & Rendah \\
\hline & 5 Tahun & 2 & 2 & 20 & 8 & Rendah \\
\hline Total & & 8 & 12 & 26 & & \\
\hline
\end{tabular}

Hasil pengamatan yang dilakukan menunjukan kolonisasi FMA pada akar kopi arabika pada beberapa varietas memiliki kriteria sangat rendah hingga rendah. Kriteria 
kolonisasi akar kriteria yang sangat rendah terdapat pada kopi arabika varietas Gayo 1 umur tiga tahun, varietas Gayo 1 umur tiga tahun, varietas Gayo 2 umur tiga tahun, varietas Gayo 2 umur lima tahun, dan varietas Ateng Super umur lima tahun. Kolonisasi akar kriteria yang rendah terdapat pada kopi arabika varietas Ateng Super umur 3 tahun, varietas Tim-Tim umur lima dan tiga tahun. Menurut Tarmedi (2006) kolonisasi FMA dapat dipengaruhi beberapa faktor yaitu suhu, pemupukan, $\mathrm{pH}$, jumlah spora dan tingkat kerentanan tanaman terhadap kolonisasi FMA.

Rendahnya koloniasi FMA pada akar tanaman kopi arabika di Kecamatan Timang Gajah diduga karena tingginya N-total dan P-tersedia pada tanah. Hasil penelitian ini menduga bahwa peningkatan persentase kolonisasi FMA tidak diikuti oleh kepadatan spora. Hal ini sejalan dengan Tahateru (2003) yang menyatakan bahwa tidak adanya hubungan erat antara persentase kolonisasi akar dan jumlah kepadatan spora yang dihasilkan, sehingga spora yang banyak belum tentu persentase kolonisasi akar akan tinggi pula.
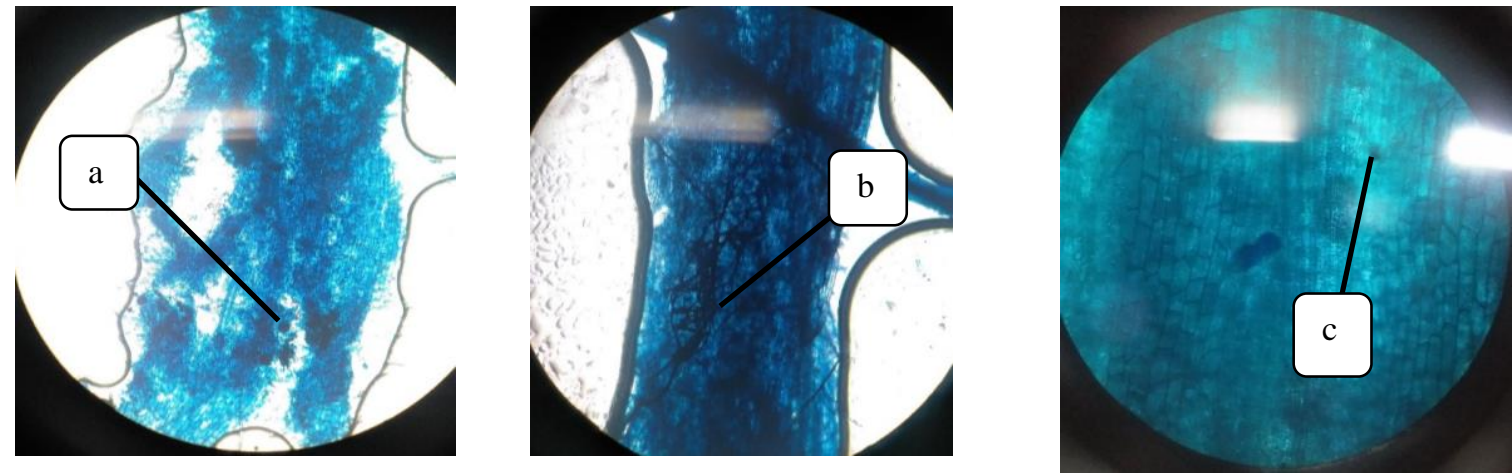

Gambar 4. Infeksi FMA pada akar beberapa varietas dan umur kopi arabika di Kecamatan Timang Gajah. Keterangan: a. Spora, b. Hifa, c. Vesikel

Hasil pengamatan kolonisasi FMA pada beberapa varietas kopi arabika di Kecamatan Timang Gajah ditemukan struktur-struktur pada akar yang terinfeksi yaitu berupa spora, hifa dan, vesikel. Sukmawati (2013), menyatakan bahwa adanya struktur-struktur tersebut menandakan terjadinya infeksi atau simbiosis FMA dengan akar tanaman.

\section{KESIMPULAN}

Terdapat tiga genus FMA yang didapat pada rizosfer beberapa varietas dan umur kopi arabika di Kecamatan Timang Gajah yaitu Glomus, Acaulospora dan, Gigaspora. Glomus adalah genus FMA yang dominan yang didapatkan pada lokasi penelitian. Terdapat Genus Glomus sebanyak dua spesies, sedangkan genus Acaulospora dan genus Gigaspora sebanyak empat spesies. Kepadatan spora FMA yang terbanyak ditemukan pada tanaman kopi arabika varietas Tim-Tim berumur lima tahun. Kolonisasi FMA pada akar kopi arabika pada beberapa varietas tergolong kriteria sangat rendah hingga rendah.

\section{DAFTAR PUSTAKA}

Abubakar, K., Darusman, dan Hifnalisa. 2018. Fractionation of fulvic and humic acid on Andisol based on altitude under organic arabica coffee at Bener Meriah District, Aceh Province. Lecturers at Soil Science Department, Faculty of Agriculture, Syiah Kuala University. 
Brundrett, M., N. Bougher, B. Dell, T. Grove, dan N. Majalaczuk. 1996. Working with mycorrhizas in forestry and agriculture. Australian Centre for International Agriculture Research (ACIAR), Canberra.

Brundrett, M. 2008. Mycorrhizal associations: The Web Resource. Section 1. Introduction school of plant biology. The University of Western, Australia.

Dariah, A., H. Subagyo, C. Tafakresnanto, dan, S. Marwanto. 2003. Kepekaan tanah terhadap erosi. Jurnal Ilmu Tanah. Jakarta.

Hanafiah, K.A. 2005. Dasar-Dasar Ilmu Tanah. PT Raja Grafindo Persada. Jakarta.

Hartoyo, B., M. Ghulamahdi., L. K. Darusman, S. A. Ariz, dan I. Mansur. 2011. Keanekaragaman fungi mikoriza arbuskula (FMA) pada rizosfer tanaman pegagan (Centella asiatica L.) Urban. Jurnal Littri. 17 (1) : 32-40.

Hasanuddin. 2003. Peningkatan ketersediaan dan serapan $\mathrm{N}$ dan $\mathrm{P}$ serta hasil tanaman jagung melalui inokulasi Mikoriza, Azotobacter dan bahan organik. Ilmu-ilmu Pertanian Indonesia. 5 (2): 83-89.

Hifnalisa, Asmarlaili, S., T. Sabrina, dan T. C. Nisa. 2017. P status in andisol and p content in arabica coffee seedling leaves due to the application of phosphate providing microorganisms and organic matters in Bener Meriah District. International Journal of Scientific \& Technology Research. 6: 59-63.

Juarti. 2016. Analisis indeks kualitas tanah andisol pada berbagai penggunaan lahan di Desa Sumber Brantas Kota Batu. Jurnal Pendidikan Geografi. 2 : 58-71.

Kaya, E. 2013. Pengaruh kompos jerami dan pupuk NPK terhadap N tersedia tanah, serapan $\mathrm{N}$, pertumbuhan dan hasil padi sawah (Oryza sativa L). Agrologia. 2(1): 1-47.

Khalid. 2017. Budidaya Kopi Arabika Gayo Secara Berkelanjutan. Kebun Percobaan (KP) Gayo, BPTP Aceh. Pondok Gajah.

LPT. 1979. Kriteria Penilaian Sifat Kimia Tanah. Lembaga Penelitian Tanah. Badan Litbang Pertanian.

Madjid, A. 2007. Dasar-Dasar Ilmu Tanah. Fakultas Pertanian Universitas Sriwijaya, Sumatera Selatan.

Manfarizah, Syamaun, dan S. Nurhaliza. 2011. Karateristik sifat fisika tanah di University Farm Stasiun Bener Meriah. Jurnal Agrista. 15(1): 6-7.

Melke, A., dan Ittana, F. (2015). Nutritional Requirement and Management of Arabica Coffee (Coffea Arabica L.) in Ethiopia: National and Global Perspektives. American Journalof Experimental Agriculture. 5(5): 30- 36.

Mukhlis. 2007. Analisis Tanah dan Tanaman. Universitas Sumatera Utara Press, Medan.

Nurmaya, G., Lahuddin, M. dan, Bintang, S. 2013. Efek interaksi pemberian silikat dan mikoriza pada andisol terhadap p-tersedia dan pertumbuhan tanaman jagung (Zea mays L.). Jurnal Online Agroekoteknologi. 2 : 294-302.

Ragupathy, S. dan A. Mahadevan. 1991. VAM distribution influenced by salinity gradient in a coastal tropical forest. Proceedings of Second Asian Conference on Mycorrhiza. Seameo Biotrop. Bogor.

Rizka F., Yuni S. R., Yuliani. 2013. Identifikasi spora jamur mikoriza vesikular arbuskular (MVA) pada tanah tercemar minyak bumi di Bojonegoro. LenteraBio 2 (1): 7-11.

Saputra, B., Riza, L. dan Lovadi, I. 2015. Jamur mikoriza vesikular (MVA) pada tiga jenis tanah rhizosfer tanaman pisang nipah (Musa paradisiaca L. var. nipa) di Kabupaten Pontianak. Protobiont 4(1):160-169.

Smith, S. E dan D. J. Read. 2008. Mycorrhizal Symbiosis. Third edition: Academic Press. Elsevier Ltd. New York, London, Burlington, San Diego 
Sri, W. B. R dan A. P. Dewi. 2016. Keanekaragaman fungi mikoriza arbuskula di bawah tanaman Jabon (Anthocephalus cadamba) di Madiun, Jawa Timur. Silvikultur Tropika. 07 (3): 146-152.

Sudaryono. 2009. Tingkat kesuburan tanah ultisol pada lahan pertambangan Batubara Sangatta, Kalimantan Timur. Jurnal Teknik Lingkungan. 10 (3): 337 - 346.

Sukarman. K dan A. Dariah. 2014. Tanah Andosol Di Indonesia Karakteristik, Potensi, Kendala, dan Pengelolaannya Untuk Pertanian. Balai Besar Penelitian dan Pengembangan Sumberdaya Lahan Pertanian. Bogor.

Sukmawati. 2013. Respon tanaman kedelai terhadap pemberian pupuk organik, inokulasi fma, dan varietas kedelai di Tanah Pasiran. Media Bina Ilmiah. 7 (4): 26-31.

Sundari, S. 2011. Isolasi identifikasi mikoriza indigenous dari perakaran Tembakau Sawah (Nicotiana tabacum L) di area persawahan Kabupaten Pamekasan Madura. Skripsi. Fakultas Matematika dan Ilmu Pengetahuan Alam Institut Teknologi Sepuluh Nopember. Surabaya.

Tarmedi, E. 2006. Keanekaragaman cendawan mikoriza arbuskuladi hutan sub pegunungan Kamojang Jawa Barat. Skripsi. Program Studi Budidaya Hutan Fakultas Kehutanan Institut Pertanian Bogor.

Tuheteru, F.D. 2003. Aplikasi asam humat terhadap sporuasi CMA dari bawah tegakan alami sengon. Skripsi. Fakultas Kehutanan Institut Pertanian Bogor. Bogor.

Usnawiyah dan Khaidir. 2013. Respon pemberian mikoriza arbuskular dalam media zeolit terhadap pertumbuhan dan hasil tanaman kedelai. Fakultas Pertanian Universitas Malikussaleh. Jurnal Agrium. 10 (1) :1-4.

Yusriadi, Y. S. Pata'dungan, dan U. Hasanah. 2018. Kepadatan dan keragaman spora fungi mikoriza arbuskula pada daerah perakaran beberapa tanaman pangan di lahan pertanian Desa Sidera. Fakultas Pertanian Universita Tadulako. Agroland 25 (1): 64-73.

Zurhalena dan Endriyani. 2004. Evaluasi status kesuburan tanah Andisol pada kebun kopi rakyat di Kabupaten Kerinci. Prosiding Seminar Nasional PLTT dan Hasil-Hasil Penelitian/Kajian Teknologi Pertanian Spesifik Lokasi Jambi, Indonesia. 